\title{
Economía, crisis y civilización
}

El sistema económico capitalista tiene fallas, es contradictorio y vulnerable, y de la estabilidad de su dinámica depende el bienestar de millones de personas. Los enfoques económicos críticos apuntan a estos problemas y a la incapacidad de las teorías dominantes para detectarlos y explicarlos. Estas voces son ignoradas o descalificadas regularmente desde el análisis dominante, aunque son retomadas cada vez que el mundo, o una parte sustancial de él, se sumerge en una crisis inesperada.

A la Economía como disciplina y a sus estudiosos se les reclama por su fijación exclusiva en cierto tipo de funcionamiento de los mercados, y su olvido de la comunidad o de las relaciones sociales que fundamentan la economía. Entre las críticas al sistema capitalista, los análisis marxistas siempre están vigentes, pero hay otras alternativas contemporáneas, como la Economía del Bien Común o el Decrecimiento, que aun viniendo de diferentes orígenes, coinciden en el análisis crítico de la economía y la necesidad de reformular los postulados de bienestar social. De los cuatro artículos elegidos entre los que respondieron a la convocatoria del tema central de este número de sociedad y economía, tres coincidieron en discutir el tema del buen vivir, mientras el cuarto artículo presenta reformulaciones críticas de los criterios de bienestar social.

Mariano Féliz aborda el tema del desarrollo económico, retomando la clasificación de desarrollismo, neoliberalismo y neo-desarrollismo para compararlos con el proyecto del buen vivir. La época del desarrollismo, comprendida entre el final de la Segunda Guerra Mundial y los años setenta, recurrió al afianzamiento del sistema capitalista por medio del crecimiento económico, aumento de la productividad y ampliación del empleo.

El neoliberalismo, que abarcó los 30 años siguientes, buscó revitalizar el sistema capitalista por medio de la liberación de mercados, la internacionalización y el desarrollo tecnológico. El neo-desarrollismo intentó superar el fracaso social del neoliberalismo con la introducción de programas de proyectos financiados trasnacionalmente. Estas fases de los enfoques de políticas económicas son comparadas con una tendencia actual que se contrapone al desarrollo capitalista: el movimiento del buen vivir.

El buen vivir surge como propuesta alternativa civilizatoria de los pueblos indígenas latinoamericanos al capitalismo y se basa en la solidaridad, cooperación y respeto a la naturaleza. Las características de este movimiento son la auto organización y gestión colectiva, la desmercantilización de las relaciones sociales, la oposición a la apropiación destructiva de la naturaleza, la promoción de 
prácticas democráticas y de nuevos mecanismos de intercambio y distribución. Como ejemplos específicos en América Latina, Féliz presenta el movimiento brasilero de los Sin Tierra, que se opone al despojo de tierras, la deforestación de la Amazonía y propone la reapropiación del suelo para la producción de alimentos; el movimiento de fábricas recuperadas en Argentina - que sugiere la capacidad de autogestión de trabajadores-, y los movimientos sociales de Bolivia que luchan por la propiedad colectiva del subsuelo y su gestión comunitaria.

Mariano Féliz realiza una crítica de las formas de la política económica y presenta el movimiento del buen vivir como la alternativa de transformación, sin cuestionarla desde ningún punto de vista. Alejandro Ramírez es más precavido acerca de las acciones políticas basadas en la idea del buen vivir. El autor, al presentar la reciente apuesta de política económica ecuatoriana, confirma que este país se encuentra bajo un modelo de neo-extractivismo progresista y no bajo un modelo de socialismo del siglo XXI. El presidente Correa, durante el segundo año de su primer gobierno, realizó una Asamblea Constituyente que incluyó el concepto indígena de buen vivir, opuesto a la noción de desarrollo o crecimiento económico, llegando incluso a titular la política de gobierno de su segundo mandato el Plan del Buen Vivir.

No obstante, según Ramírez, a pesar de esta adhesión al buen vivir, durante la administración del presidente Correa se fomentaron nuevas normas legales para actividades mineras y petroleras sin consulta previa. El autor reconoce que se han hecho políticas redistributivas y de asistencia social, que han mejorado las condiciones de vida de la población ecuatoriana, pero dependientes de una economía basada en la extracción de recursos naturales. Incluso, afirma el autor, estas políticas sociales permiten aliviar el descontento de la población. Este artículo pone en entredicho la adopción del buen vivir como horizonte incuestionable de política social, ya que la simple adhesión a sus preceptos no garantiza coherencia entre las distintas acciones de política, al menos en el caso ecuatoriano.

Julián Sabogal Tamayo coincide con los anteriores autores en reconocer la crisis capitalista y propone una alternativa que coindice con el buen vivir. El autor expone los evidentes - y nunca suficientemente tratados- problemas del capitalismo: la extrema desigualdad en la distribución de la riqueza y el ingreso, la degradación ambiental y la crisis de valores. Afirma que la solución a sus problemas fundamentales no es posible dentro del mismo sistema, y se arriesga a proponer lo que ha denominado como Modo de Vida Alternativo, cuyo fundamento se encuentra en el concepto ancestral del bien vivir.

¿Cómo puede una sociedad lograr el bienestar o el buen vivir de sus miembros? La pregunta que atraviesa a los cuatro artículos del tema central es tratada por Diego Fernando Martínez desde el pensamiento económico normativo de John Rawls. Según el autor, para Rawls la propuesta del utilitarismo de maximizar la utilidad del conjunto de miembros de la sociedad es peligrosa porque define lo que es bueno independientemente de lo que es justo. Este es un juicio de valor que no tiene en cuenta lo que una sociedad considera bueno, y reduce lo que es justo a la maximización de la utilidad. Lo que interesa no es la maximización de la utilidad, sino encontrar un principio normativo fundamentado. 
A partir de principios básicos se puede evaluar aspectos relevantes del sistema económico. Por ejemplo, según el principio de la diferencia una situación desigual solo es tolerable si beneficia a la persona menos aventajada. En este caso, una situación desigual puede ser eficiente, en el sentido que no es posible mejorar el bienestar de alguien sin perjudicar a otro, pero según el principio de la diferencia entre las opciones de asignaciones eficientes, es preferible aquella que mejora la situación de las personas menos aventajadas. De igual forma, los mercados también pueden ser evaluados: ellos ofrecen libertades pero regularmente, a la vez, ignoran las necesidades de las personas, así que un sistema de impuestos y transferencias puede garantizar a los menos aventajados un nivel de ingreso básico.

Fabio Alberto Arias Arbeláez ${ }^{1}$ Profesor e investigador de la Universidad del Valle fabio.arias@correounivalle.edu.co

Boris Salazar Trujillo² Profesor e investigador de la Universidad del Valle boris.salazar@correounivalle.edu.co 
